\title{
EFFECT OF HEIGHT OF TRIANGULAR SIIL ON THE PERFORMANCE OF STILLING BASIN MODEL
}

\author{
H. L. Tiwari ${ }^{1}$, V.K.Gehlot ${ }^{2}$, Seema Tiwari ${ }^{3}$ \\ ${ }^{2}$ Department of Civil Engineering, Maulana Azad National Institute of Technology, Bhopal, Madhya Pradesh India \\ ${ }^{2}$ Department of Civil Engineering, Maulana Azad National Institute of Technology, Bhopal, Madhya Pradesh India \\ ${ }^{3}$ AISECT University, Bhopal, India
}

\begin{abstract}
This research paper investigates the effect of height of triangular intermediate sill on the performance of stilling basin models for non circular pipe outlet. The experimental study was carried out for three Froude numbers namely 3.85, 2.85 and 1.85 for non-circular pipe outlet. Performance index (PI) has been used to evaluate the performance of stilling basin models tested using same sand base material and test run time. The scour pattern was measured for each test run and flow pattern was also observed. After 24 tests runs, it was found that scour process were reduced for a particular height of triangular of intermediate sill combined with end sill of particular size and shape. Performance of this model was found to be better than USBR VI impact basin for similar flow condition.
\end{abstract}

Keywords: Intermediate sill, pipe outlet, stilling basin, Scour pattern.

\section{INTRODUCTION}

Stilling basins are normally used in reducing the excess energy downstream of hydraulic structure like over flow spillway, sluices, pipe outlets, etc. The effect of sill on the flow and or scour characteristics depends upon the configuration of the sill, its geometry and the flow regime, Negm (2004). Various types of recommended stilling basin designs for pipe outlets are by Bradely and Peterka (1957), Fiala and Maurice(1961), Keim (1962), Flammer et al. (1970), Vollmer and Khader (1971), Verma and Goel (2000 \& 2003), Goel (2008), Tiwari et al. (2011, 2012 \&2013), Tiwari and Gahlot (2012) and Tiwari (2013 \& 2013). Appurtenances play an important role in the reduction of kinetic energy of flowing water in the stilling basin. A stilling basin for a pipe outlet consists of appurtenances like splitter block, impact wall, intermediate sill and an end sill etc. The vertical end sill is a terminal element in the stilling basin, which has a great contribution in reduction of energy of flowing sheet of water and assists in to improve the flow pattern downstream of the channel thereby helps in reducing the length of stilling basin also.

The sill height, configuration and position have great impact on the formation and control of hydraulic jump and ultimately leading to the dissipation of energy of flowing water. The present research paper concentrates on the improvement of the performance of stilling basin model by using triangular intermediate sill of varying height along with end sill and impact wall. Performance of stilling basin models is compared with performance index (PI). Higher value of PI indicates better performance of the model (Tiwari et al.2014).

\section{EXPERIMENTAL ARRANGEMENT AND PROCEDURE}

The experiments were conducted in a recirculating laboratory flume of $0.95 \mathrm{~m}$ wide $1 \mathrm{~m}$ deep and $25 \mathrm{~m}$ long. The width of flume was reduced to $58.8 \mathrm{~cm}$ by constructing a brick wall along the length for keeping ratio of width of basin to equivalent diameter of rectangular outlet equal to 6.3 as per design of Gardes et al. (1986). A rectangular pipe of $10.8 \mathrm{~cm}$. $x 6.3 \mathrm{~cm}$. was used to represent the outlet flow. The exit of pipe was kept above stilling basin by one equivalent diameter $(1 \mathrm{~d}=9.3 \mathrm{~cm})$. To observe the scour after the end sill of stilling basin a erodible bed was made of coarse sand passing through IS sieve opening $2.36 \mathrm{~mm}$. and retained on IS sieve opening $1.18 \mathrm{~mm}$. The maximum depth of scour $(\mathrm{dm})$ and its distance from end sill (ds) was measured for each test after one hour run time. The depth of flow over the erodible bed was maintained equal to the normal depth of flow. The model stilling basin USBR type VI, proposed by Bradley and Peterka (1957) was fabricated with impact wall of size $20.46 \mathrm{~cm} . x 58.8$ $\mathrm{cm}$ with hood of size $9.3 \mathrm{~cm} \times 58.8 \mathrm{~cm}$ and sloping end sill of height $9.3 \mathrm{~cm}$ and base width $9.3 \mathrm{~cm}$ was fabricated. The discharge was measured by a calibrated venturimeter installed in the feeding pipe. With the operation of tail gate the desired steady flow condition with normal depth was maintained. After one hour the test run, motor was switched off. The value of maximum depth of scour $(\mathrm{dm})$ and its location from the end sill (ds) were noted. USBR VI model was tested with impact wall and end sill and then again models were tested with seven different intermediate sills. All tested models with appurtenances are shown in Figures 1 to 3 . All the testing were performed for constant running time of one hour and 
with the same erodible material for three Froude numbers ie,3.85, 2.85 and 1.85. Further scouring pattern was observed by using triangular intermediate sill of different height, kept at the distance of $4 \mathrm{~d}$ from the exit of the pipe, thus total 24 test runs were performed to evaluate the performance of stilling basin models by using intermediate sill of different height. Scheme of experimentation is shown in Table 1.

Table 1 Scheme of Experimentation

\begin{tabular}{|c|c|c|c|c|c|c|c|c|}
\hline \multicolumn{9}{|c|}{$\begin{array}{l}\text { Testing of Models to Study the Height effect of Intermediate Sill with Triangular End Sill (1V:1H) } \\
\text { of height } 1 \mathrm{~d} \text { for Basin Length 8.4d on the performance of stilling basin model }\end{array}$} \\
\hline \multirow[b]{2}{*}{ S.N. } & \multirow[b]{2}{*}{$\begin{array}{l}\text { Model } \\
\text { Name }\end{array}$} & \multicolumn{3}{|c|}{ USBR VI Impact Wall with hood } & \multicolumn{4}{|c|}{ Intermediate sill } \\
\hline & & Size & $\begin{array}{l}\text { Bottom } \\
\text { gap with } \\
\text { basin floor }\end{array}$ & $\begin{array}{l}\text { Location } \\
\text { from } \\
\text { outlet } \\
\text { exit } \\
\end{array}$ & Shape & Height & Width & $\begin{array}{l}\text { Location } \\
\text { from } \\
\text { outlet exit }\end{array}$ \\
\hline 1 & MSM-6 & $1 \mathrm{~d} \times 2.2 \mathrm{~d}$ & $1 \mathrm{~d}$ & $3 \mathrm{~d}$ & - & - & - & - \\
\hline 2 & MSM-18 & $1 \mathrm{~d} \times 2.2 \mathrm{~d}$ & $1 d$ & $3 d$ & $\begin{array}{l}\text { Triangular } \\
\text { with vertical } \\
\text { face D/S }\end{array}$ & $2.5 \mathrm{~d}$ & $1 d$ & $4 d$ \\
\hline 3 & MSM-19 & $1 \mathrm{~d} \times 2.2 \mathrm{~d}$ & $1 d$ & $3 d$ & $\begin{array}{l}\text { Triangular } \\
\text { with vertical } \\
\text { face } D / S\end{array}$ & $2 d$ & $1 d$ & $4 d$ \\
\hline 4 & MSM-20 & $1 \mathrm{~d} \times 2.2 \mathrm{~d}$ & $1 d$ & $3 \mathrm{~d}$ & $\begin{array}{l}\text { Triangular } \\
\text { with vertical } \\
\text { face } D / S\end{array}$ & $1.5 \mathrm{~d}$ & $1 d$ & $4 d$ \\
\hline 5 & MSM-21 & $1 \mathrm{~d} \times 2.2 \mathrm{~d}$ & $1 d$ & $3 \mathrm{~d}$ & $\begin{array}{l}\text { Triangular } \\
\text { with vertical } \\
\text { face D/S }\end{array}$ & $1 d$ & $1 \mathrm{~d}$ & $4 d$ \\
\hline 6 & MSM-22 & $1 \mathrm{~d} \times 2.2 \mathrm{~d}$ & $1 d$ & $3 \mathrm{~d}$ & $\begin{array}{l}\text { Triangular } \\
\text { with vertical } \\
\text { face } D / S\end{array}$ & $\mathrm{~d} / 2$ & $1 \mathrm{~d}$ & $4 d$ \\
\hline 7 & MSM-23 & $1 \mathrm{~d} \times 2.2 \mathrm{~d}$ & $1 d$ & $3 \mathrm{~d}$ & $\begin{array}{l}\text { Triangular } \\
\text { with vertical } \\
\text { face } \mathrm{D} / \mathrm{S}\end{array}$ & $1 d$ & $\mathrm{~d} / 2$ & $4 d$ \\
\hline 8 & MSM-24 & $1 \mathrm{~d} \times 2.2 \mathrm{~d}$ & $1 d$ & $3 d$ & $\begin{array}{l}\text { Triangular } \\
\text { with vertical } \\
\text { face } D / S\end{array}$ & $\mathrm{~d} / 2$ & $\mathrm{~d} / 2$ & $4 d$ \\
\hline
\end{tabular}

\section{CRITERIA FOR PERFORMANCE OF}

\section{EVALUATION FOR A STILLING BASIN}

A stilling basin model that produces smaller depth of scour at a longer distance is considered to have a better performance as compared to another stilling basin which results in a larger depth of scour at a shorter distance when tested under similar flow condition Verma \& Goel (2003). The performance of a stilling basin models were tested for different Froude number $(\mathrm{Fr})$ which is a function of channel velocity $(\mathrm{v})$, the maximum depth of scour (dm) and its location from end sill (ds). A new non dimensional number, called as performance index (PI) developed by Tiwari et al (2011) has been used for comparison of performance of stilling basin models. This is given as below:

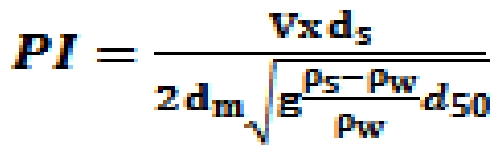

Where, V - the mean velocity of channel, ds - distance of maximum depth of scour from end sill, dm- depth of maximum scour, $g$ - gravitation acceleration, $\rho s-$ density of sand, $\rho w$ density of water, d50- the particle size such that $50 \%$ of the sand particle is finer than this size, A higher value of performance index indicates a better performance of the stilling basin model. The value of Performance index for various runs on each model for different Froude numbers are given in Table 2. 


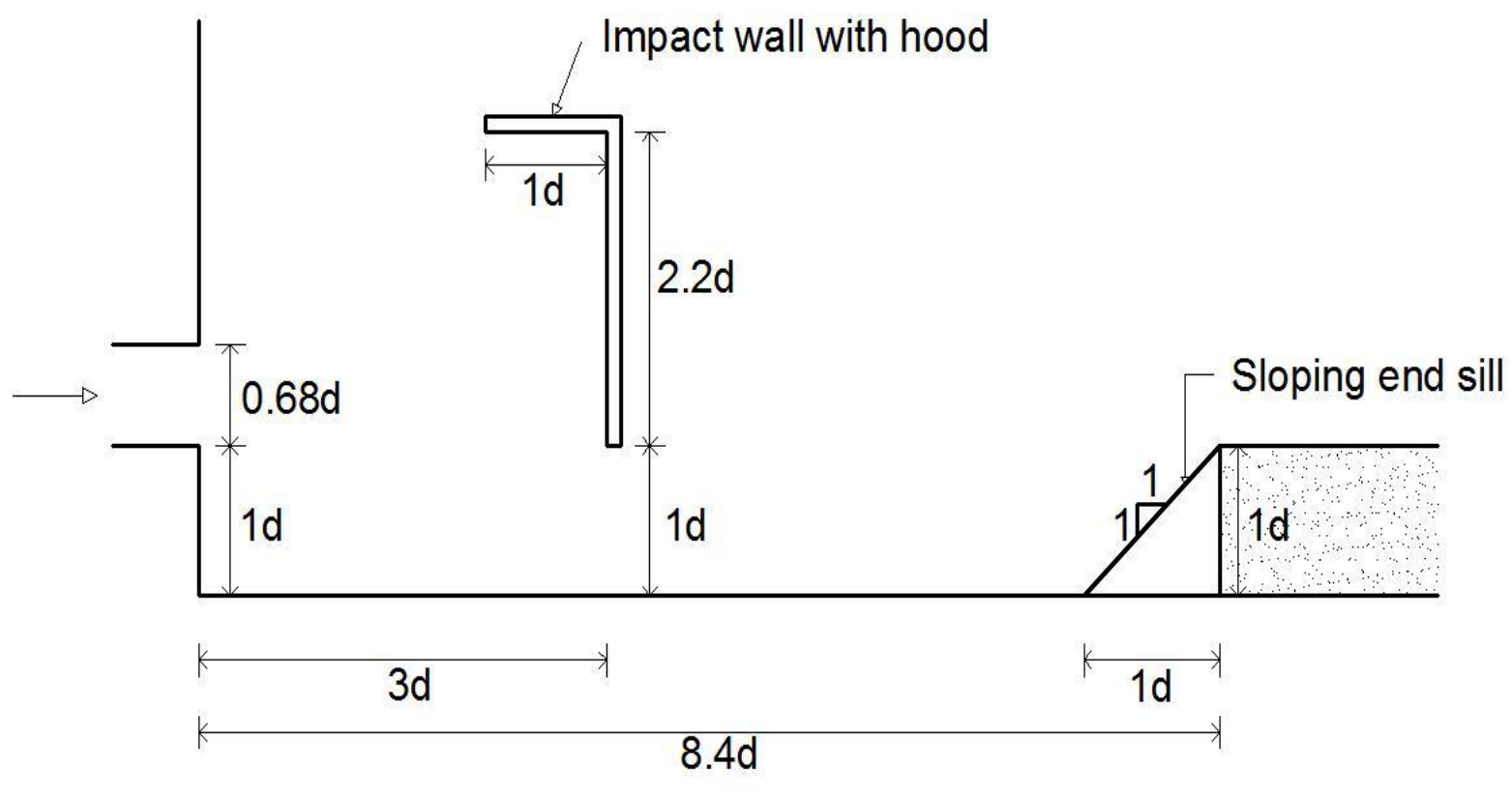

MSM-6

Fig 1 USBR VI Stilling basin model (Models MSM-6)

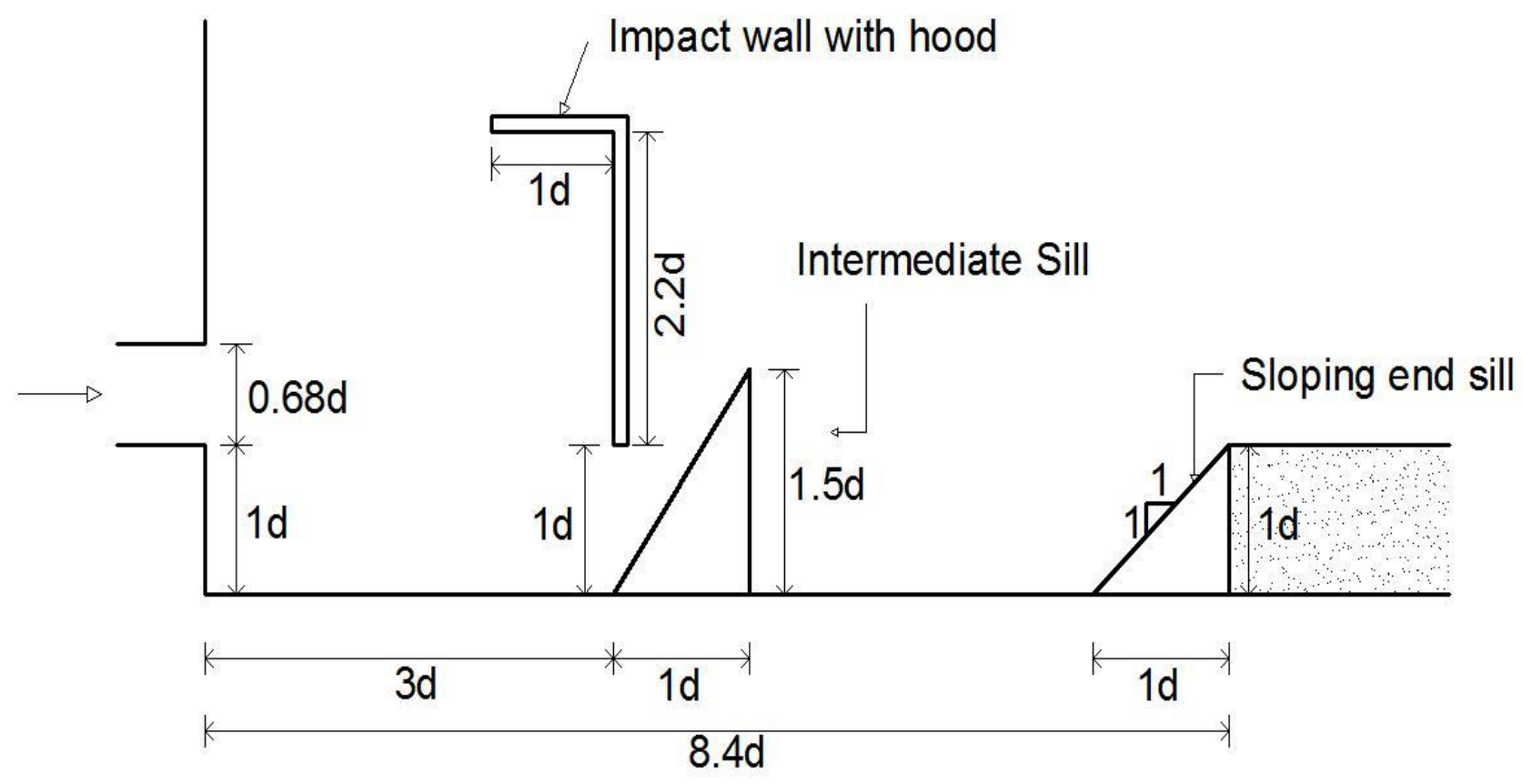

MSM-20

Fig 2 Model MSM-20 with USBR VI Impact Wall, Sloping End Sill and Intermediate Sill of height 1.5d with Vertical Face Downstream 


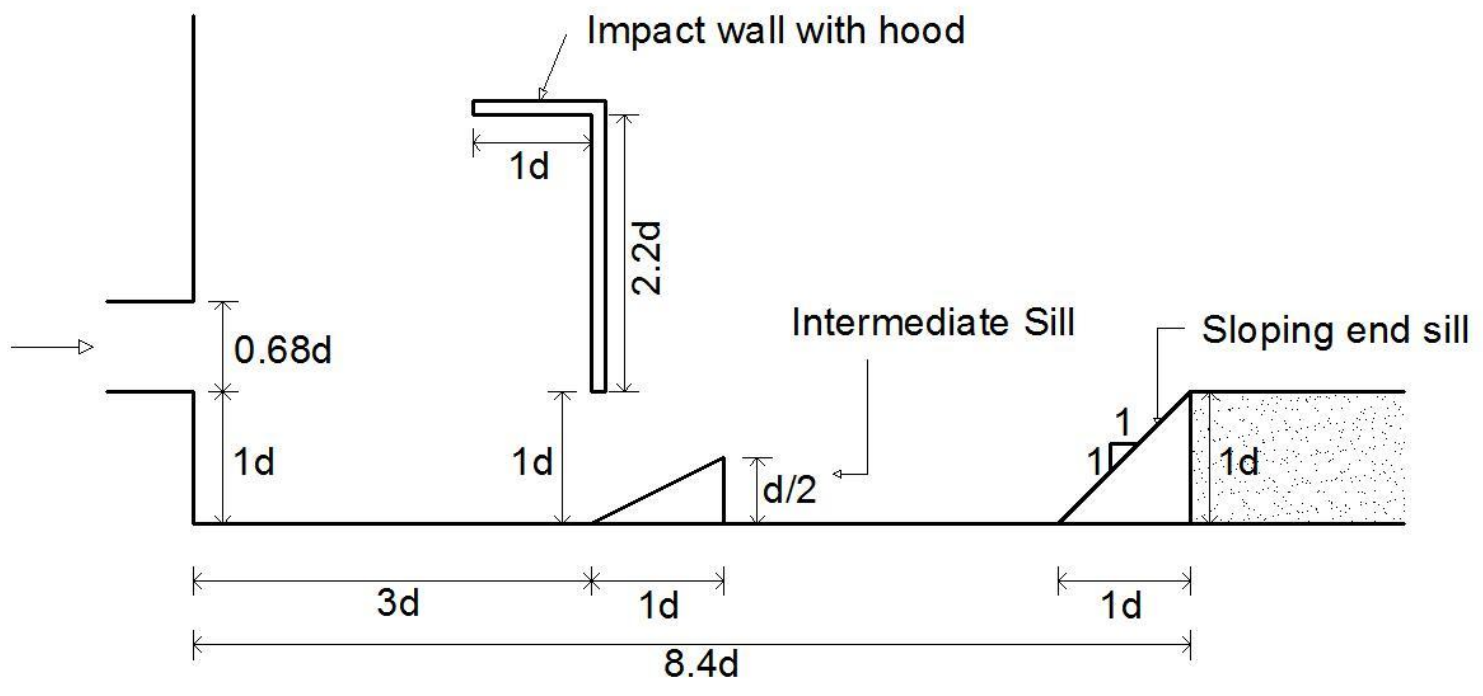

MSM-22

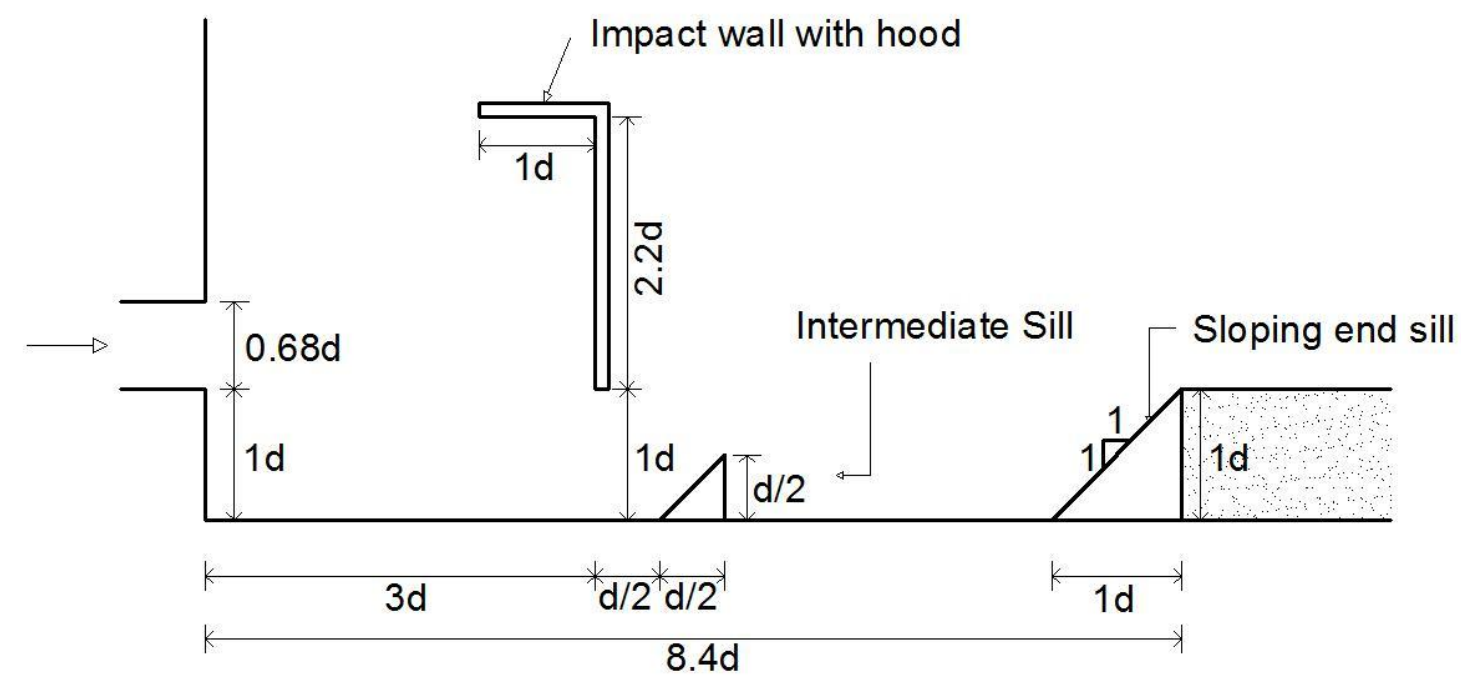

MSM-24

Fig 3 Models MSM-22 and MSM-24 with USBR VI Impact Wall, Sloping End Sill and Intermediate Sill of height 1d and 0.5d and base width $0.5 \mathrm{~d}$ with Vertical Face Downstream

\section{RESULTS AND ANALYSIS}

To study the effect of height of triangular intermediate sill on the performance of stilling basin models for pipe outlet, seven models, were tested for three Froude numbers, namely 1.85 , 2.85 and 3.85. The data pertaining to depth of scour and its location from end sill were collected for each model and reported in table 2 to evaluate their performance by using performance index. First of all USBR VI model (MSM-6) was tested and values of PI was computed as 2.67, 2.63 and 3.42 for $\mathrm{Fr}=1.85,2.85$ and 3.85 respectively.
In continuation of the investigation of the height of triangular intermediate sill, the performance of the basin models were tested with triangular intermediate sill of varying height from $2.5 \mathrm{~d}$ to $0.5 \mathrm{~d}$ with same base width as $1 \mathrm{~d}$ along with impact wall located at $3 \mathrm{~d}$ and sloping end sill fixed at $8.4 \mathrm{~d}$. These models were named as MSM-18, MSM-19, MSM-20, MSM21 and MSM-22 respectively. It was reported that by reducing the height of triangular intermediate sill from $2,5 \mathrm{~d}$ to $0.5 \mathrm{~d}$ in model MSM18 to MSM-22, the performance of model (MSM2) improved as compared to the performance of model (MSM18) for Froude number $1.85,2.85$ and 3.85 ,because PI values 
increases to $5.19,4.64$ and 5.03 from $3.55,3.68$ and 3.88 as shown in Table 2.Further models MSM-23 and MSM-24 were tested with reduced width as $0.5 \mathrm{~d}$ and height $1 \mathrm{~d}$ and $0.5 \mathrm{~d}$ of triangular intermediate sill. It was found that there is no improvement of performance as compared to model MSM-22. Though it was reported that by inserting the intermediate of any height performance of model improved as compared to USBR VI(MSM-6) model as shown in Table2.

Table 2 Performance index for different models tested with ES, IW and IS

\begin{tabular}{|l|l|l|l|l|l|l|l|l|l|l|}
\hline S. & \multirow{2}{*}{$\begin{array}{l}\text { Model } \\
\text { No. }\end{array}$} & \multicolumn{4}{l}{ Fr $=1.85$} & \multicolumn{4}{l}{ Fr $=2.85$} & \multicolumn{2}{l|}{ Fr=3.85 } \\
\cline { 3 - 11 } & name & ds & PI & dm & ds & PI & dm & ds & PI \\
\hline 1 & MSM-6 & 3.2 & 10.5 & 2.67 & 4.4 & 12.5 & 2.63 & 4.6 & 15.5 & 3.42 \\
\hline 2 & MSM-18 & 1.9 & 8.6 & 3.55 & 2.9 & 11.5 & 3.68 & 3.8 & 14.5 & 3.881 \\
\hline 3 & MSM-19 & 2.4 & 10.2 & 3.460 & 2.8 & 11.3 & 3.745 & 3.2 & 12.5 & 3.973 \\
\hline 4 & MSM-20 & 1.9 & 10.2 & 4.370 & 2.5 & 12.1 & 4.492 & 4.2 & 16.3 & 3.947 \\
\hline 5 & MSM-21 & 1.4 & 7.9 & 4.593 & 2.4 & 11.8 & 4.563 & 3.1 & 13.4 & 4.396 \\
\hline 6 & MSM-22 & 0.8 & 5.1 & 5.19 & 1.3 & 6.5 & 4.64 & 1.9 & 9.4 & 5.03 \\
\hline 7 & MSM-23 & 0.9 & 5.7 & 5.155 & 3.3 & 11.8 & 3.318 & 4.3 & 16.4 & 3.879 \\
\hline 8 & MSM-24 & 1.2 & 6.5 & 4.409 & 1.6 & 6.2 & 3.596 & 2.6 & 9.9 & 3.872 \\
\hline
\end{tabular}

After analysis, it was found that by changing the height of triangular intermediate sill there is improvement in the performance of the basin. It is so because of impact action, a reduction of energy is more, thereby improvement of the basin performance. Intermediate sill of suitable height promotes the dissipation of energy in the basin by lifting high velocity filaments from the bed. No doubt performance of the stilling basin models improves with the inclusion of intermediate sill, which also confirms the findings of Negm (2007).Similar finding was also reported by Tiwari \& Tiwari (2013) and Tiwari et al. (2014).

\section{CONCLUSIONS}

An experimental investigation was conducted to study the effect of height of triangular inter mediate sills along with impact wall and end sill. Seven intermediate sills of different height varying from $2,5 \mathrm{~d}$ to $0.5 \mathrm{~d}$ were tested. The scouring is significantly reduced there by increasing the performance index for triangular intermediate sill of height $0.5 \mathrm{~d}$ and base width $\mathrm{d}$, placed at the distance of $4 \mathrm{~d}$ from the exit of pipe outlet. It is found that triangular intermediate sill of height $0.5 \mathrm{~d}$ and base width as $1 \mathrm{~d}$, used in model MSM-22, produces higher performance indices and thus performs better as compared to all other tested models for all Froude numbers tested. Based on the results of experimental studies on stilling basin models, it can be concluded that the height of triangular intermediate sill greatly affect the performance of a stilling basin. Efficient stilling basin model (MSM-22) has been evolved by experimentation as compared to USBR VI stilling basin model, MSM-6.

\section{REFERENCES}

[1] Bradley, J.N., Peterka, A. J. 1957, Hydraulic Design of Stilling Basins, Journal of A.S.C.E., Hydraulic Engg, , 83(5), 1401-1406.

[2] Fiala, J. R. and Maurice, L. A. 1961, Manifold Stilling Basins, Journal of A.S.C.E., Hydraulic Div.. 87(4), pp.55-81.

[3] Garde, R .J., Saraf, P.D., Dahigaonkar, D.J. 1986, Evolution of Design of Energy Dissipator for Pipe Outlets, J. of Irrigation \& Power, 41(3) ,145-154.

[4] Goel, A. 2008, Design of Stilling Basin for Circular Pipe Outlet. Canadian Journal of Civil Engineering, 35 (12), pp. 1365-1374.

[5] Keim, S. R. 1962, Contra Costa Energy Dissipator. Journal of A.S.C.E., Hydraulic Division, 3077, March, , pp. 109-122.

[6] Negm, A.M. 2004, Effect of sill arrangement on maximum scour depth DS of abruptly enlarged stilling basins. Proc. of Int. Conf. Hydraulics of Dams and River Hydraulics, 26-28 April, Tehran, Iran.

[7] Tiwari, H.L., Goel, A. and Gahlot, V.K. 2011, Experimental Study of Sill Controlled Stilling Basins for Pipe Outlet, International Journal of Civil Engg. Research, 2(2), 107-117.

[8] Tiwari, H.L., Goel, A. and Gahlot, V.K. 2011, Experimental Study of effect of end sill on stilling basin performance, International Journal of Engg. Sci. and Technology, 3(4), 3134-3140.

[9] Tiwari, H.L, Gahlot, V.K. and Tiwari Seema, 2013, Reduction of Scour depth downstream of stilling basin, International Research Journal of Engineering Sciences. 2(7), pp.20-25. 
[10] Tiwari, H.L.and Gahlot, V. K. 2012, Experiments on new Stilling basin for Pipe outlets, STM, AISECT University, 2(2), pp. 17-20.

[11] Tiwari, H.L. 2013, Design of Stilling Basin with Impact wall and End sill, International Research Journal of Resent Sciences, 2(3), pp.59-63.

[12] Tiwari, H.L. 2013, Analysis of Baffle wall gap in the Design of Stilling Basin Models , International Journal of Civil Engineering and Technology, .4( 4), pp.6671.

[13] Tiwari, H.L. and Tiwari Seema 2013, Design of Stilling Basin Models with Intermesiate sill , Journal of Science, Technology and Management, 2( 4), pp.66-71.

[14] Tiwari, H.L, Gahlot, V.K. and Abhay Sharma, 2014, Effect of of Intermediate sill on the performance of of stilling basin models, International Journal of Sc. Engineering \& Technology, 3(4), pp..

[15] Vollmer, E., Khader, M.H.A. 1971, Counter Current Energy Dissipator for Conduit Outlets, International J. of Water Power, 23(7), 260-263.

[16] Verma, D.V.S, Goel, A. 2000, Stilling Basins for Outlets Using Wedge Shaped Splitter Blocks, ASCE Journal of Irrigation and Drainage Engineering126 (3), 179-184.

[17] Verma, D.V.S., Goel, A. 2003, Development of Efficient stilling basins for Pipe Outlets, ASCE Journal of Irrigation and Drainage Eng..129(3), 194-200. 